\title{
BioLink
}

Jurnal Biologi Lingkungan, Industri, Kesehatan

Available online http://ojs.uma.ac.id/index.php/biolink

\section{ESTIMATION OF NUMBERS OF COLIFORM BACTERIAL AS WATER QUALITY INDICATOR IN KEPAHIANG DISTRICT RIVERS, BENGKULU PROVINCE}

\author{
Sipriyadi *, Risky Hadi Wibowo, \& Welly Darwis \\ Department of Biology, Faculty of Mathematics and natural Sciences, Universitas Bengkulu, \\ Indonesia
}

Submited : 07-06-2020; Reviewed :11-06-2020; Accepted : 27-11-2020

*Corresponding author: E-mail : sipri vadi@yahoo.co.id

\begin{abstract}
Coliform is a group of microbes that are used as indicators of water quality. Water pollution is generally caused by pathogenic microbes from feces, household waste, and industrial activity waste. This study aimed to estimate the total number of coliform contamination in several rivers in Kepahiang Regency, namely Tebat Monok (TM), Sempiyang (SPY), Penanjung Panjang (PP), Embong Ijok (EI) Air Langkap(ALK), and Air Belimbing (ABB). Total coliform and Fecal coliform tests were carried out using the Most Probable Number (MPN) method on Lactose Broth, Brillian Green Lactose Bile Broth and pour plates on Eosin Methylene Blue Agar media. Measurement of abiotic factors was on temperature and pH parameters. The test results of total coliform showed that 6 rivers contained total coliform under the Class II river water quality standards with a range of $1210 / 100 \mathrm{~mL}-4310 / 100 \mathrm{~mL}$ and 2 rivers that were contaminated with Fecal coliform, TM and ALK, have the content of 1500/100 mL and $1700 / 100 \mathrm{~mL}$. The results of the measurement of the abiotic factor, the river $p H$ range was 7.4 - 8.2. The lowest temperature was $250 \mathrm{C}$ in $S P Y$ river and the highest temperature was 26 oC on the TM, PP, EI, ALK, and ABB rivers.
\end{abstract}

Keywords: Water Quality; Coliform; Abiotic Factors

How to Cite: Sipriyadi, Wibowo, R.H. \& Darwis, W. (2021). Estimation of Numbers of Coliform Bacterial as Water Quality Indicator in Kepahiang District Rivers, Bengkulu Province, BioLink: Jurnal Biologi Lingkungan, Industri dan Kesehatan, Vol.7 (2): Hal. 154-163 


\section{INTRODUCTION}

Water is a basic need for living things on earth that determines health and wellbeing (Cahyadi et al., 2011; Sumantri, 2013). One of the water source with great potential is river water. According to Government Regulation No.38/2011 on rivers, rivers play an important role as a provider of water to meet household needs, environmental sanitation, agriculture, industrial activities, tourism, sports, defense, fish farming, power generation, and transportation.

In general, the rivers in Kepahiang Regency are the upstream parts of the rivers in Bengkulu Province and the source of water from rivers which eventually empties into larger rivers, such as the Musi river. The rivers are used by the community for various kinds of daily activities, especially for bathing, washing and latrines, for irrigation and fisheries, landfills, and household waste including the excretions of the community itself. Domestic waste that has polluted rivers physically, chemically and biologically has decreased the quality of the river water. Decreasing water quality can be seen from several factors, including temperature, $\mathrm{pH}, \mathrm{BOD}$, COD, oxygen solubility, Total Dissolved Solids (TDS), and microorganisms such as coliform. To be more specific, tests were carried out to determine the concentration of Total Coliform, Fecal Coliform and Escherichia coli.

Coliform is bacteria that generally found in soil and water, where the activities of humans and animals greatly affect its life. Fecal Coliform is a group of Total Coliform that can only live in the digestive tract of mammals (Arisanty et al., 2017; Sari \& Situmorang, 2020). The determination of coliform bacteria as an indicator of water pollution is due to its density having a positive correlation with the level of water pollution (Prayitno, 2009). The objective of this study was to determine the quality of river water in Kepahiang Regency, Bengkulu Province based on the estimated number of coliform bacteria contamination, $\mathrm{pH}$, temperature, and several other water abiotic factors.

\section{MATERIALS AND METHODS}

This research was conducted in May - July 2018 in Kepahiang Regency. Sampling was carried out in six rivers in Kepahiang Regency, namely Tebat Monok (TM), Sempiyang (SPY), Penanjung Panjang (PP), Embong Ijok (EI), Air Langkap (ALK), and Air Belimbing (ABB). The measurement of water temperature and $\mathrm{pH}$ parameters, The parameters of river water quality were done using measurement include Oxygen Demand (D0), electrical conductivity (DHL), Chemical oxygen demand (COD), Total Suspended solids (TSS), and Total 155 
dissolved solids (TDS) of river was carried out directly in the field. Meanwhile, analysis of Bological Oxygen Demand (BOD) and microbiology were carried out at the Microbiology Laboratory, Faculty of Mathematics and Natural Sciences, Bengkulu University.

\section{Total Coliform and Fecal Coliform Test}

This test was performed to determine the Most Probable Number (MPN) of coliform and fecal coliform bacteria in 100 $\mathrm{mL}$ water samples. This MPN test used 3 prediction series, namely $10 \mathrm{~mL}, 1 \mathrm{~mL}$, and
$0.1 \mathrm{~mL}$ and was carried out in three repetitions (triplo). This test consists of two stages, namely the presumptive test and the Confirmed test.

The presumptive test was carried out by inoculating the water sample into LB media serial $10 \mathrm{~mL}, 1 \mathrm{~mL}$, and $0.1 \mathrm{~mL}$. Then the LB media was incubated for 24 hours at $37^{\circ} \mathrm{C}$. Furthermore, the observation of the gas formed in each durham tube was carried out. Each tube with a positive test result was continued to the stage of confirmation test.

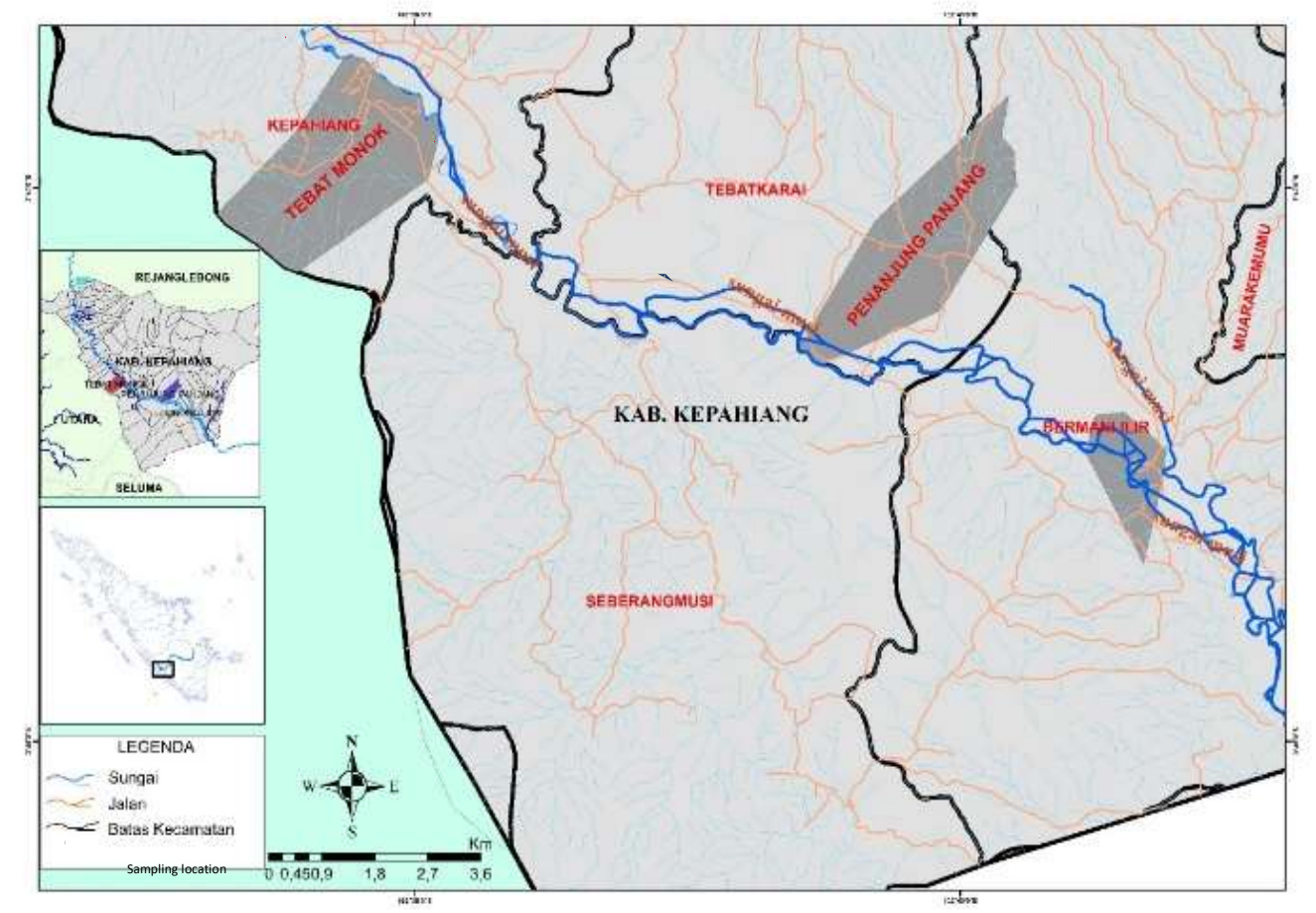

Ficture 1. Location Water sampling at six locations of river water flow leading to Musi River

The confirmation test was carried out observation of the gas bubbles in each by inoculating the positive results of the durham tube was carried out. The number prediction test into BGLBB media with the of positive tubes converted refers to the same series, followed by incubation for 24 MPN series 333 table according to the hours at $37^{\circ} \mathrm{C}$. Furthermore, the re- Thomas Formula (Soemarno, 2000). 
Coliform bacteria density analysis was calculated according to SNI 06-4158-1996 with the formula:

The confirmation test was carried out by inoculating the positive results of the prediction test into BGLBB media with the same series, followed by incubation for 24 hours at $37^{\circ} \mathrm{C}$. Furthermore, the reobservation of the gas bubbles in each durham tube was carried out. The number of positive tubes converted refers to the MPN series 333 table according to the Thomas Formula (Soemarno, 2000). Coliform bacteria density analysis was calculated according to SNI 06-4158-1996 with the formula:

Total Colifrom Bacteria (JPT / $100 \mathrm{~mL}$ ) =

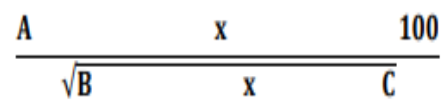

Note:

A: The number of tubes is positive

$B$ : Volume $(\mathrm{mL})$ of specimen in the negative tube

C: Volume $(\mathrm{mL})$ of specimen in all tubes

\section{Test for the content of Escherichia coli bacteria}

The E. coli content test is a complementary test (Complete test). This test was carried out by spreading as much as $0.1 \mathrm{~mL}$ of the positive result of the confirmation test which had been diluted into EMBA media and incubated for 24 hours at $37^{\circ} \mathrm{C}$. The presence of E. coli was indicated by the presence of metallic green bacterial colonies on the surface of the EMBA media.

\section{RESULTS AND DISCUSSION}

River Water Abiotic Factors

Temperature

The water quality of the temperature parameters of the six rivers in Kepahiang Regency is presented in Figure 1. The temperature measurement results obtained did not vary too much, ranging from $25-26^{\circ} \mathrm{C}$.

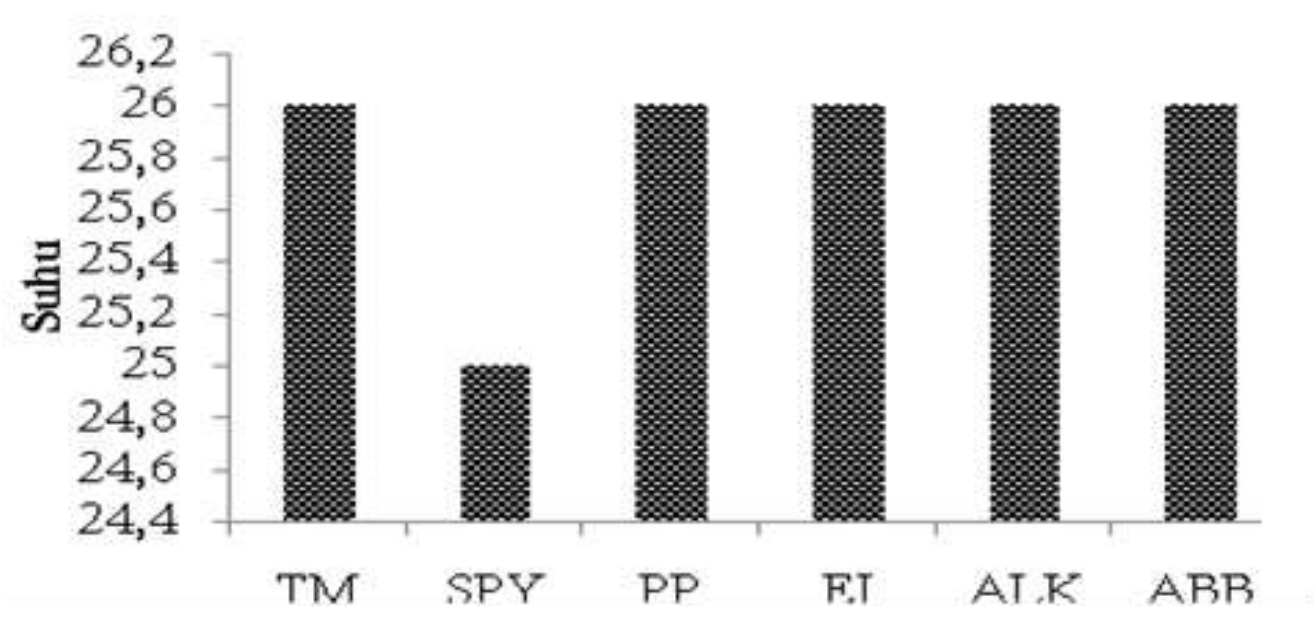

Figure 2. Average river water temperature in Kepahiang Regency. TM (Tebat Monok), SPY (Sempiyang), PP (Penanjung Panjang), EI (Embong Ijok), ALK (Air Langkap), ABB (Air Belimbing) 
Temperature is caused by the alkalinity of a liquid and indicates the presence of heat in the surface of the water hydrogen ion concentration (Soewandita \& due to the absorption of solar radiation by the water surface. The measurement results showed that the water temperature in several rivers in Kepahiang Regency ranges from $25-26^{\circ} \mathrm{C}$. The lowest temperature was in the Sempiyang River (SPY) which is $25^{\circ} \mathrm{C}$ and the temperature of the other rivers is at $26^{\circ} \mathrm{C}$. The difference in temperature was caused by human activity factors such as waste disposal into rivers and loss of river body protectors (Fitra, 2008).

\section{Degree of Acidity (pH)}

$\mathrm{pH}$ is an important limiting factor in aquatic environments. It is since most water biota are very sensitive to changes in $\mathrm{pH}$ values. The $\mathrm{pH}$ value shows the level of
Sudiana, 2010).

The $\mathrm{pH}$ parameter of all the rivers monitored showed that the $\mathrm{pH}$ of the water in several rivers in Kepahiang Regency still met the criteria for class II river water quality standards, namely pH 6-9 (Figure 2) based on Bengkulu Provincial Government Regulation Number 6 of 2005. The lowest $\mathrm{pH}$ was found in Sempiyang River (SPY) is 7.4 and the highest was in the Embong Ijok River (EI), which is 8.2. Yuliastuti (2011) states that the increase in $\mathrm{pH}$ value is influenced by inorganic and organic waste discharged into the river. The $\mathrm{pH}$ value of a water is influenced by several factors such as the content of organic matter, $\mathrm{CO}_{2}$ content, and mineral content or alkalinity (Ibrahim et al., 2019).

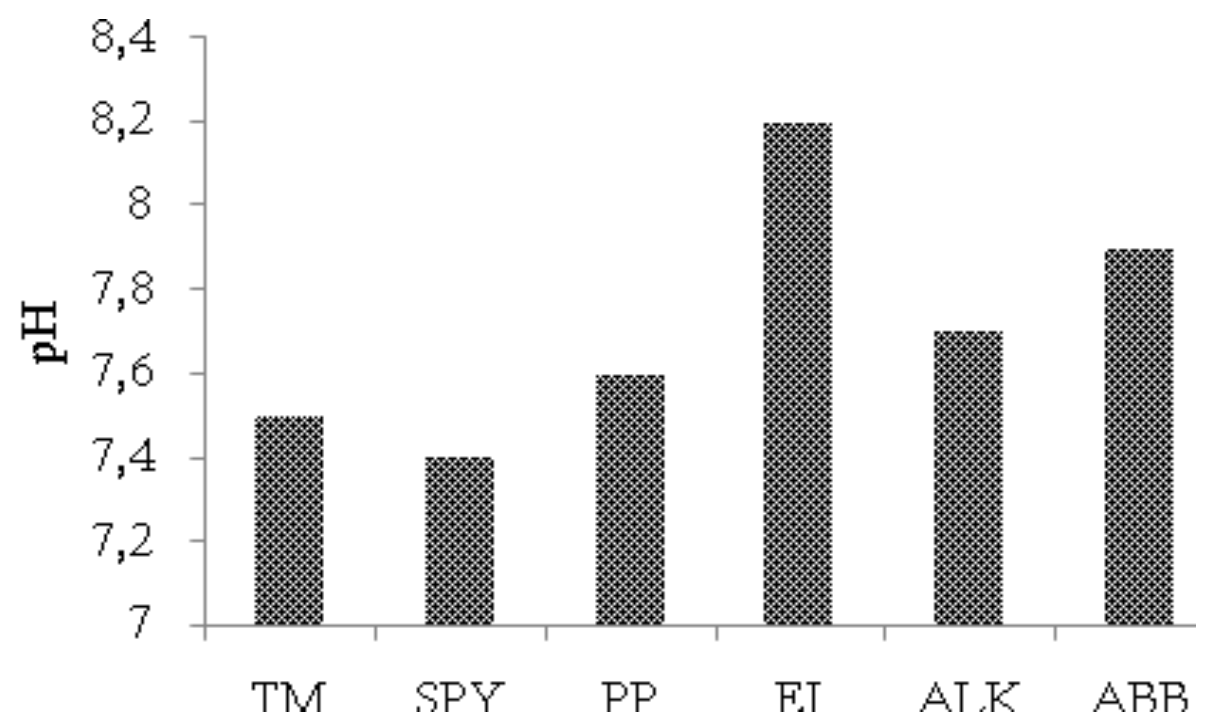

Figure 3. The average pH of river water in Kepahiang Regency. TM (Tebat Monok), SPY (Sempiyang),PP (Penanjung Panjang), EI (Embong Ijok), ALK (Air Langkap), ABB (Air Belimbing) 
The measurement of River Water Chemical Oxygen Demand (COD), Bological Parameters

River water quality parameters that were measured include Dissolved Oxygen (DO), Electrical Conductivity (DHL), Oxygen Demand (BOD), Total Suspended Solid (TSS), and Total Dissolved Solid (TDS).

Table 1. Data results of Measurement of water parameters

\begin{tabular}{cccccccccc}
\hline \multirow{2}{*}{ No. } & \multicolumn{2}{c}{ Sample } & \multicolumn{9}{c}{ River name } & \multicolumn{2}{c}{ Standard } \\
\cline { 2 - 10 } & Parameter & Unit & TM & SPY & PP & EI & ALK & ABB & Water class II \\
\hline 1 & DO $^{*}$ & Mg / L & 5.23 & 3.14 & 5.85 & 5.46 & 5.18 & 5.17 & 4 \\
2 & DHL $^{*}$ & US & 372 & 650 & 244 & 465 & 259 & 577 & - \\
3 & COD & Mg / L & 7,18 & 4,3 & 7.75 & 13.49 & 10.05 & 15.79 & 25 \\
4 & BOD & Mg / L & 2.51 & 1.42 & 0.73 & 0.99 & 0.26 & 1.58 & 3 \\
5 & TSS $*$ & Mg / L & 14 & 10 & 88 & 248 & 50 & 0.106 & 1000 \\
6 & TDS & Mg / L & 164 & 230 & 50 & 116 & 196 & 262 & 50 \\
\hline
\end{tabular}

Note: * data obtained directly from the field, while the ones are not marked * means data from laboratory analysis

Based on Table 1 above, it can be seen that the important parameters in determining the quality of river water in these 6 rivers show varied results. For DO parameters, of the 6 rivers measured, 5 of them showed results that exceeded the prerequisite Class II water quality standards. Meanwhile, 1 river that still has DO levels below the Class II water quality standard is Sampeyang river water. DO, is the amount of dissolved oxygen in water that was used as a parameter to see water quality, because oxygen is needed by aquatic biota for both metabolic and respiration processes. Low or high DO was caused by temperature (oxygen levels become lower as temperature increases), rate of photosynthesis by aquatic plants, metabolic rate of aquatic organisms, and sensitivity of organisms to toxic wastes, parasites, and disease.
The causes of temperature changes include weather and shady riverbank vegetation removal, the lower the concentration, the lower the water quality can disrupt the balance of the aquatic ecosystem which is characterized by the death of biota such as fish, aroma and aesthetics (Spellman \& Drinan 2012), for parameters DHL, COD, BOD, and TSS showed results that were still below the threshold for class II water quality standards, meaning that they still had a fairly good quality for class II river water. DHL is the ability of a solution to deliver electric current. The greater the DHL value, the more minerals are contained in the water (Sriyono et al., 2019). COD is the amount of oxygen (mg $\left.\mathrm{O}_{2}\right)$ needed to oxidize organic substances in one liter of water sample, COD value for water pollution is $150 \mathrm{mg} / \mathrm{L}$ if it exceeds the 
threshold value, it means that there is an indication of organic matter contamination in these waters (Widayanti, et al., 2012),

BOD is a measure of dissolved oxygen consumed by microorganisms during oxidation of reduced substances in the water and waste (Bhateria \& Jain, 2016). TSS indicates water pollution by suspended solids, the TSS value for water pollution is $50 \mathrm{mg} / \mathrm{L}$, if the value of suspended solids increases significantly, the waters will look turbid and look dirty (Atima, 2015). The research conducted by Djaharam et al., (2018) in the Pesanggrahan River, DKI Province, showed that it had water quality with polluted status from light to moderate, with the results of the measurement of the abiotic factors for the BOD and TSS parameters that have exceeded the limit based on the quality standard for class II. Similar results were also reported by Mardhia and Abdullah (2018), the water quality of the Brangbiji river based on $\mathrm{pH}$, temperature, TDS, TSS, BOD, COD, and ammonia parameters exceeded the maximum water quality standards for Class I and II, but still met the standards for quality standards. water class III and IV.

\section{Test of Total Coliform and Fecal Coliform}

The results obtained from six rivers in Kepahiang Regency where the samples taken were all the tubes had gas bubbles and the media became more turbid, so that the river water samples tested were stated as positive for coliform bacteria (Figure 4).

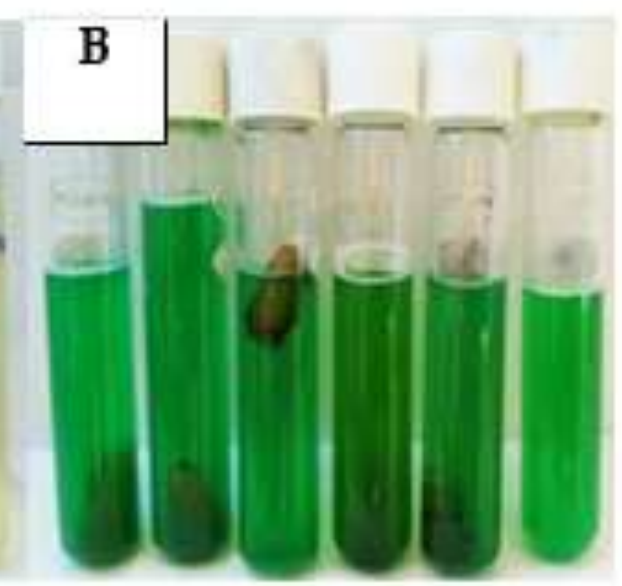

Figure 4. The result of presumative test using LB media (A) and Confirmation test using BGLBB media (B)

The presence of this bacterial was still below the threshold for class II indicator concludes that river water had water quality standards, namely 5000/100 undergone biological contamination. Total $\mathrm{mL}$. The highest total coliform content was coliform pollution in the six rivers of in the Air Langkap (ALK) river, namely Kepahiang Regency was quite high, but it $4310 / 100 \mathrm{~mL}$ and the lowest was in the 
Sipriyadi, Wibowo, R.H., \& Darwis., W. Estimation of Numbers of Coliform Bacterial as Water Quality Indicator in Kepahiang District Rivers, Bengkulu Province

Penanjung Panjang (PP) river, namely 1210/100 mL (Table 1).

The results of the confirmed test showed that there were two rivers that did not meet the class II water quality standards (1000/100 $\mathrm{mL})$, namely the Sungai Monok (TM) with 1500/100 mL of fecal coliform and Air Langkap (ALK) river with fecal coliform as much $1700 / \mathrm{mL}$.
For fecal coliform contamination from Sempiyang (SPY), Penanjung Panjang (PP), Embong Ijok (EI), and Air Belimbing (ABB) rivers, they still meet the criteria for class II water quality standards. The results of microbiological analysis of the four rivers showed that the fecal coliform value was under 1000/100 mL.

Table 2. Total coliform and fecal coliform bacteria in several rivers in Kepahiang Regency

\begin{tabular}{cccc}
\hline No. & River & $\begin{array}{c}\text { Total Coliform (Qty / 100 } \\
\text { mL) }\end{array}$ & $\begin{array}{c}\text { Fecal Coliform } \\
\text { (Qty / 100 mL) }\end{array}$ \\
\hline 1. & TM & 3240 & $1500^{*}$ \\
2. & SPY & 1980 & 280 \\
3. & PP & 1210 & 100 \\
4. & EI & 2910 & 500 \\
5. & ALK & 4310 & $1700^{*}$ \\
6. & ABB & 2200 & 800 \\
\hline
\end{tabular}

Note : ${ }^{*}$ is above the standard threshold for class II water standards

Samples of river water contaminated with coliform bacteria came from anthropogenic activities, especially disposal of household waste, industrial activities, and agriculture to river water without prior treatment. In addition, the majority of people in Kepahiang Regency made their living as farmers and also used animal manure as fertilizer. Based on Shafi et al. (2013), the use of animal waste as fertilizer for agriculture also triggers an increase in the number of coliform bacteria.

The complementary test results showed that the water samples tested positive contained E. coli bacteria (Figure 5). It is indicated by the metallic green color of the bacterial colonies grown on EMBA media. The high activity of the population in settlements was one of the roots of the increasing frequency of waste disposal into river, both waste from the activities of the population itself and waste from industrial activities surrounding. These environmental conditions had the potential to increase the concentration of coliform bacteria including E. coli (Arifudin et al., 2013; Dasopang, 2017; Ramadhianto \& Nasution, 2019). 


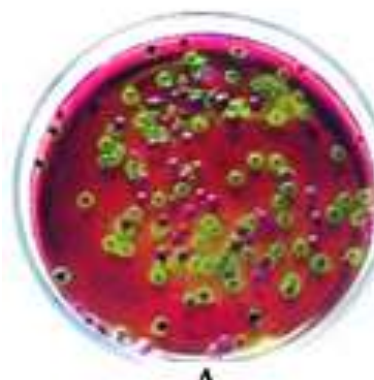

A

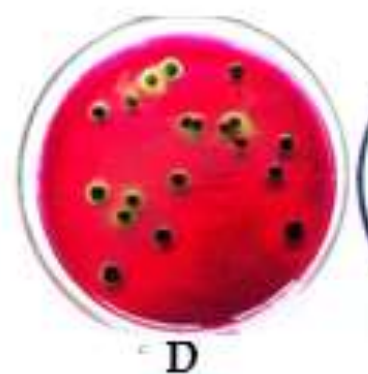

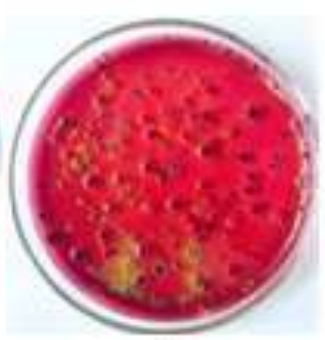

B

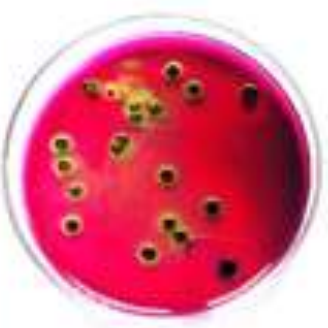

C

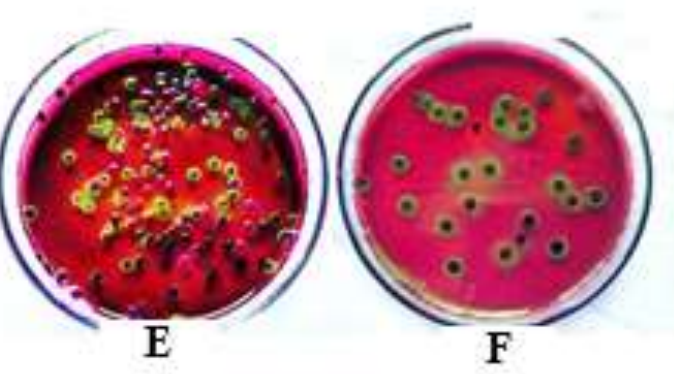

Figure 5. Colon morphology of E. coli on EMBA media after incubation for 24 hours at $37^{\circ} \mathrm{C} . \mathrm{A}=\mathrm{Tebat}$ Monok (TM), B = Sempiyang (SPY), C = Penanjung Panjang (PP), D = Embong Ijok (EI), E = Air Langkap $(\mathrm{ALK}), \mathrm{F}=$ Air Belimbing $(\mathrm{ABB})$

\section{Based on the temperature CONCLUSION} measurements carried out in the six observation rivers, the river water temperature was relatively stable, ranging from $25-26^{\circ} \mathrm{C}$. Based on Hidayati et al. (2006), the optimum temperature for the growth of coliform bacteria was $37{ }^{\circ} \mathrm{C}$. Based on the optimum growth temperature, Lay and Hastowo (1992) classified bacteria into three, namely psychrophilic (0-20 $\left.{ }^{\circ} \mathrm{C}\right)$, mesophilic (20-50 $\left.{ }^{\circ} \mathrm{C}\right)$, and thermophilic $\left(50-100{ }^{\circ} \mathrm{C}\right)$. The coliform bacteria found in the rivers of Kepahiang Regency were mesophilic group bacteria seen from the water temperature at the time of sampling.
Total coliform test showed that the six observation rivers were still under the standard threshold for class II water quality standards. The fecal coliform test indicates that Tebat Monok (TM) and Air Langkap (ALK) rivers had criteria that did not meet the class II water quality standards with 1500/100 mL and 1700/100 mL fecal coliform content,

\section{REFERENCES}

Arifudin, S., Khotimah, S., \& Mulyadi, A. (2013). Analisis Sebaran Bakteri Coliform di Kanal A Kaula Dua Kabupaten Kubu Raya. Jurnal Protobion, 3 (2), 186-192.

Arisanty, D., Adyatma, S., \& Mulyadi, A. (2017). Analisis Kandungan Bakteri Fecal Coliform pada Sungai Kuin Banjarmasin. Majalah Geografi Indonesia, 31 (2), 50-6o.

Atima, W. (2015). BOD dan COD sebagai Parameter Air dan Baku Mutu Air Limbah. 
Jurnal Biologi Science dan Education, 4 (1), 83-98.

Bhateria, R., \& Jain, D. (2016). Water quality assessment of lake water: a review. Sustainable Water Resources Management, 2 (1), 161-173.

Cahyadi, A., Priadmodjo, A., \& Yananto, A. (2011). Criticizing the Conventional Paradigm of Urban Drainage. Proceeding the $3^{\text {rd }}$ International Graduated Student Conference on Indonesia. Yogyakarta: Sekolah Pascasarjana Universitas Gadjah Mada, 547553.

Dasopang, E.S. (2017), Skrining Fitokimia dan Uji Aktivitas Antibakteri Ekstrak Etanol Daun Sangitan (Sambucus javanica Reinw) Terhadap Pertumbuhan Bakteri Eschericia coli dan Salmonella thypi, Jurnal BioLink, Vol. 4 (1): Hal. 54-62

Djaharam, V., Etty, R., \& Mohamad, Y. (2018). Analisis Kualitas Air dan Daya Tampung Beban Pencemaran Sungai Pesanggrahan Di Wilayah Provinsi DKI Jakarta. Jurnal Pengelolaan Sumber Daya Alam dan Lingkungan, 8 (1), 127-133.

Fitra, E. (2008). Analisis Kualitas Air dan Hubungannya dengan Keanekaragaman Vegetasi Aquatik di Perairan Perapat Danau Toba. Medan: Universitas Sumatera Utara.

Hidayati, Y. A., Harlia, E., \& Suryanto, D. (2006). Deteksi Jumlah Total Bakteri Coliform pada Kompos Kotoran Domba sebagai Indikator Sanitasi Lingkungan. Lokakarya Nasioanal Keamanan Pangan dan Produk Peternakan. Fakultas Peternakan, Universitas Padjadjaran: Bandung.

Ibrahim, A., Nasution, S.H., Lukman., Rahmadya, A. 2019. Kualitas Perairan Danau Siais Periode Maret 2019. Prosiding Pertemuan Ilmian Tahun Ke-IV MLI, 25-37.

Lay, B. W., \& Hastowo, S. (1992). Mikrobiologi. Jakarta: Rajawali Press.

Mardhia, D., \& Abdullah, V. (2018). Studi Analisis Kualitas Air Sungai Brangbiji Sumbawa Besar. Jurnal Biologi Tropis, 18 (2), 182-189.

Peraturan Pemerintah Nomor 38 Tahun 2011, tentang sungai. 1-58.

Prayitno, A. (2009). Uji Bakteriologi Air Baku dan Siap Konsumsi dari PDAM Surakarta Ditinjau dari Jumlah Bakteri
Coliform.Skripsi. Surakarta: Universitas Muhammadiyah

Surakarta.(http://eprints.ums.ac.id/3821/1 /A420040040.pdf) diakses 19 September 2019.

Ramadhianto, A., \& Nasution, J. (2019). Bioaktivity Test Crude Fruit of Citrus Lime (Citrus aurantifolia) on Bacteria Escherichia coli in Vitro. Budapest International Research in Exact Sciences (BirEx) Journal, 1(2), 16-20

Sari, Y., \& Situmorang, N. (2020). Pengaruh Jarak Kandang Ternak Terhadap Total Coliform Pada Air Sumur Gali Di Desa Klambir. BIOLINK : Jurnal Biologi Lingkungan Industri Kesehatan, 6(2), 186195.

Shafi, S., Kamili, A. N., Shah, M. A., \& Bandh, S. A. (2013). Coliform Bacterial Estimation: A Tool for Assessing Water Quality of Manasbal Lake of Kashmir, Himalaya. African Journal of Microbiology, 7 (31), 3996-400o.

Spellman FR \& Drinan JE. (2012). The drinking water handbook, 2nd edn. Boca Raton: CRC Press

Soemarno. (2000). Isolasi dan Identifikasi Bakteri Klinik.Akademisi Analis Kesehatan Yogyakarta. Yogyakarta: Departemen Kesehatan Republik Indonesia.

Soewandita, H., \& Sudiana, N. (2010). Studi Dinamika Kualitas Air DAS Ciliwung. JAI, 6(1), 24-33.

Sriyono, E., Sardi, \& Kresnanto, N. C. (2019). Assessment of the quality of well water in the spatial terraces of river code in Yogyakarta Indonesia. First International Conference of Construction, Infrastructure, and Materials, 650, 1 - 9.

Sumantri, A. (2013). Kesehatan Lingkungan. Jakarta: PT Fajar Interpramata Mandiri.

Widayanti, G., Didik, S. W., \& Abdul, H. (2012). Elektrodekolorisasi Perairan Tercemar Limbah Cair Industri Batik dan Tekstil di Daerah Batang dan Pekalongan. Jurnal Kimia Sains dan Aplikasi, 15 (2), 62-69.

Yuliastuti, E. (2011). Kajian Kualitas Air Sungai Ngringo Karanganyar dalam Upaya Pengendalian Pencemaran Air. Tesis. Semarang: Program Pascasarjana Universitas Diponegoro. 